\title{
The Utilization of Local Wisdom of the Pusuk Buhit Community, Sianjur Mula-Mula District, in Tourism Development in Samosir Regency, North Sumatera Province
}

\author{
R. Hamdani Harahap ${ }^{1}$, Yeni Absah ${ }^{2}$ \\ ${ }^{1}$ Social Anthropology Departement, Faculty of Social and Political Science Universitas Sumatera Utara, Jl. Prof. A. \\ Sofian No 1 Kampus USU Medan 20155 \\ ${ }^{2}$ Management Departement, Faculty of Economic and Bussiness, Universitas Sumatera Utara, Jl. Prof TM Hanafiah. \\ Kampus USU Medan 20155 \\ Email:r.hamdani@usu.ac.id,yeni.absah@usu.ac.id
}

\begin{abstract}
The Lake Toba area, which is one of the priority tourist destinations in Indonesia, has a variety of local wisdom that can be used for tourism development. This study analyzes what local wisdom in Pusuk Buhit is still guided by and which has been lost in today's daily life. Next, we will analyze the reasons behind the low tourist visits to Pusuk Buhit, Samosir Regency, which has an extraordinary natural and cultural heritage base. The research was conducted with a qualitative descriptive method. Data was collected using in-depth interviews, combined with field observations and FGDs with several key informants, namely community leaders, several NGOs. The results showed that some of the local wisdom found in Pusuk Buhit, Samosir Regency is still used as a way of life, but some of it is no longer used as a way of life. Most of the tourists who visit the local wisdom location in the area of Pusuk Buhit, Sianjur Mula-Mula Sub-district, do religious tour; they come to perform their pilgrimage to the local wisdom location. Stories about the local wisdom are not uniform, and they are usually interpreted by the speakers differently, based on their own religion. The reasons of tourists are reluctant to visit the local wisdom location is because of lack of transportation to the location, the location is far from the hotels where the tourists stay, there is no inn or motel in the local wisdom location, tourists need extra energy to reach the area of Pusuk Buhit, lack of information about the existence of the local wisdom, lack of service in the local wisdom location, lack of facility for the tourists to relax, lack of toilets/bath rooms, lack of restaurants or food stands, and sanitation and hygienic condition in the local wisdom location are very bad.
\end{abstract}

Keywords: Pusuk Buhit area, local wisdom, Lake Toba tourism

\section{BACKGROUND}

Lake Toba is the most valuable asset of the North Sumatera Provincial Government; it is the third DTW (Tourist Destination) in Indonesia. In the last two decades, this area underwent degradation from various aspects which decreased the quality of its environment and beautiful panorama. The national and international care for this tourist destination is clearly be seen from various brochures which attract the attention of all people to improve the beauty of Lake Toba. This tourism object should be managed properly to be a tourist destination in order to avoid the conflict of using/utilizing this area (Sianturi, 2004).

Samosir Regency is one of the seven regencies in the vicinity of Lake Toba. There are six problems which rise concerning the development of Lake Toba: preservation of water resources, fishery and environment, agriculture and plantation, culture, tourism, and infrastructure (Sinaga, 2018).

One of the cultural discussions and its relation to tourism is local wisdom. According to Ahimsa-Putra (2009), local wisdom is the instrument of knowledge and practices in a certain community which comes, either from the previous generation or from the experience in environment and other communities, to settle any problems and/or difficulties that have legal and not legal enforcement. Traditional wisdom is different from local wisdom. In the local wisdom, the emphasis is on places and localities of the wisdom so that local wisdom should not always be inherited from generation to generation. It is a new form of wisdom in a community as the result of interaction among people 
and other cultures. Therefore, local wisdom is not always traditional since it can include today's wisdom, and thus it can have broader meaning than that of traditional wisdom.

The concept of local wisdom is often used in character building and environmental management. Some writings have discussed about local wisdom related to Lake Toba tourism. Keliat (2020) wrote about the potentials of thinking about establishing Sitamiang Village, Oman Runggu Sub-district, Samosir Regency, as a local wisdom based-tourist village. Some other writers wrote about the influence of local wisdom on local economic development in the tourism area of Lake Toba, Parapat. There is the mean value of the variable of tangible local wisdom which has bad category (the score is under 4) in Sipangan Bolon Sub-district, Simalungun Regency; it is the indicators of infrastructure condition tourism, culturally protected area, mythic condition, and lake/waters tourism. Intangible local wisdom also has bad category (the score is under 4) which is the indicators of honesty, gentleness, full of attention, negotiation, and courteousness (Siregar, 2018).

There is also a research on space structuring of the water's edge by revitalizing the area through instilling some new functions which will be conceived through the analysis of characters, potency, and problems of area in Tano Ponggol Pangururan, Samosir Regency (Tri and Aulia, 2019). Besides that, there is a research which explores featured products of Tomok Village which is a tourist destination of Lake Toba Geopark Caldera (Panggabean, et. al., 2020). Along with the explanation above, a research on the value of Sigale-gale dance should be maintained by reintroducing its show like its former appearance and introducing reliable dancers in attracting tourists to dance (manortor) (Andriani, et. al., 2019). There is also a research which analyzes the Tongging Village area as a part of KSN (National Strategic Area) of Lake Toba; it is situated in Karo Regency which is also a part of Toba Geopark Caldera area.

Pardede and Suryawan (2016) find some problems concerning tourism in Samosir Regency such as lack of people's interest in environmental conservation, lack of their hospitality toward tourists from foreign countries, low productivity rate of the people, lack of reliable human resources that can manage tourism, lack of promotion in organizing entertainments in Samosir, lack of facilities, infrastructure, and sanitation at every tourism object in Samosir, and most of the remaining sites of archeological find and artifacts are owned by the clans so that the government get difficulties in managing them.

Of the various researches which have been done, only a few of them which talk about the connection of the existence of local wisdom with the tourism development, especially in the tourism object of Pusuk Buhit, Sianjur Mula-Mula Sub-district, Samosir Regency, North Sumatera Province. Therefore, the writer is interested in doing a research on the use of local wisdom in developing tourism at Pusuk Buhit, Samosir Regency.

\subsection{Formula of the Problems}

Based on the background above, it was necessary to formulate the research problems: how were the form and the function of local wisdom in the tourism area of Pusuk Buhit, Sianjur Mula-Mula Sub-district, Samosir Regency, North Sumatera Province? What were the tourists' responses to the existence of local wisdom in the tourism area of Pusuk Buhit, Sianjur Mula-Mula Subdistrict, Samosir Regency, North Sumatera Province?

\subsection{Objective of the Research}

The objective of the research was

1. to analyze the form and the function of local wisdom in the tourism area of Pusuk Buhit, Sianjur Mula-Mula Sub-district, Samosir Regency, North Sumatera Province.

2. to analyze the tourists' responses to the existence of local wisdom in the tourism area of Pusuk Buhit, Sianjur Mula-Mula Sub-district, Samosir Regency, North Sumatera Province.

\section{LITERATURE REVIEW}

\subsection{Lake Toba Tour}

Lake Toba offers 3 (three) components as a tourist destination: lake natural tour, geopark tour, and local culture (Batak). Lake Toba as the KSPN (National Tourism Strategic Area) which vovers 7 (seven) regencies surrounding Lake Toba; they are Toba Samosir, Samosir, Simalungun, Tapanuli Utara, Karo, Humbang Hasundutan, and Dairi. The development of tourism (attraction, amenity/comfort, and accessibility) becomes the prameter of the success in developing tourism in a certain area, including tourism area of Lake Toba (Widhijanto and Tisnaningtyas, 2018).

There are 5 (five) tour activities in the area of Lake Toba: beach tour, hill tour, wet rice field tour, grave tour, and adat house tour. These tour activities can be used as a model of structuring and guideline for local wisdom based-activities as the priority of Lake Toba tourism (Irsan, et. al., 2020). Jaya (2019) analyzes the environment of the tourism area of Lake Toba as the basis for developing an alternative model of environmental management. The management of tourism in Lake Toba should be increased and developed in the environmental perspective and in the sustainable development.

In the last five years, however, there were only a few tourists who visited Lake Toba. Siregar, et. al. (2018) points out that accessibility is needed in developing tourism area of Lake Toba in Toba Samosir Regency. It must be an effort to provide and to increase the accessibility Besides that, Lumbanraja et. al. (2019) point out that the role of creative tourism and green tourism marketing in creating attractive tourism experience and tourist satisfaction are still low. 
Sihombing, et. al. (2019) point out that people's tourism awareness has positive and significant influence on the development of tourism in Tapanuli Regency. The government should carry out the program of increasing people's tourism awareness. It is recommended that the government program in Developing Tourism Area of Lake Toba be supported in order to attract tourists to visit the area. This will have the impact on regional development through the increase in domestic income, people's income, employment, and socialization of local culture, tourism location allotment in keeping cleanliness and environmental beauty, creating order, and security and comfort for various types of visitors who have different religion, races, and nationalities.

\subsection{Social Capital and Lake Toba Tourism}

Principally, social capital is concerned with social bond or cohesiveness. The central idea of social capital about social bond is that network is a very valuable asset - a basis for social cohesiveness since it encourages cooperative climate in order to get the benefit (Field, 2010). In reality, it uses correlation to work together to help people improve their lives (Putnam, 2000: 19; Woolcock, 1998 in Field, 2010). The social relations can be empowered as capital in order to get not only economic benefit but also social one (Usman, 2018). Syahra (2003) points out that social capital plays an important role in every aspect of development: politics, economy, human beings, and culture. This is because social capital emphasizes on the importance of maintaining good relationship and trust among people.

Revida, et. al. (2018) find positive and significant influence of Social Capital on the People's Service Quality of Tourism in Lake Toba Parapat, North Sumatera. Social capital such as trust, norms, network, and people's service quality of tourism such as tangibles, reliability, responsiveness, assurance, and empathy should be increased by providing communication, information, and education continuously from family, formal and informal institutions, public figures, religious leaders, and the people as a whole in Lake Toba Parapat, North Sumatera

\subsection{Local Wisdom}

Local wisdom is a philosophy of life, attitude, and guideline for behavior in helping people survive from various threats which will disturb them from natural disaster and the dynamics of life. Mungmachon (2012) points out that local wisdom will be able to give the solution of the problems faced by the people, especially environmental problems. Maturbongs, et. al. (2017) find some examples of local wisdom used to conserve environment such as awigawig local wisdom in North Lombok, oral tradition in Wakatobi, and cosmological Melayunese tradition in order that the same thing can be implemented in other places in Lombok which is in accordance with the potency of local wisdom in every region in conserving environment. The values of local wisdom should be the regulation in itself or in accordance with the government's policy on managing and protecting environment.

The research done by Harahap and Humaizi (2017) analyzes the existence of local wisdom owned by the Batak Toba community at Silalahi village I, Silalahi Sabungan Sub-district in preserving Lake Toba. It is found that the people at this village consider that Lake Toba is the source of life. It means that Lake Toba is the source of income, the source of livelihood such as fishing, the place for floating net cages, and the device for supporting tourism activities. The form of local wisdom in preserving the area of Lake Toba is the existence of sacred places such as Naulibasa and Batu Partonunan (Deang Namora) in which the whole area of Lake Toba, called Tao Silalahi, is controlled by Namboru Deang Namora. People are prohibited to spit, to wear ornaments, to do immoral acts, to bathe after 6 o'clock, to bring or to consume pork or dog meat, to bathe nakedly in the lake, and to roar with laughter or guffaw; a woman who wants to bathe in the lake has to tie her long hair, and everyone who wants to bathe in the lake has to ask permission from his nenek (oppung), the guard of the lake. This whole local wisdom has to be obeyed even though some people do not adhere to them. The effective way to revitalize the wisdom of the local people is by continuously do the Tugu Silahisabungan ritual or ceremony once a year and by always obey the advice given by the Raja Silahisabungan that is called, podasagu-sagumarlangan

Collaboration is the keyword in developing the relation among the actors that are gathered in developing local wisdom based-tourism. This study attempts to describe and analyze pentahelix collaboration in the local wisdom based-tourism. Maturbongs and Lekatumpessy (2020) point out that local wisdom based-tourism with collaboration among the actors in a pentahelix model prioritizes all forms of uniqueness which grow and develop in the society and provides agricultural values which use materials and non-materials.

\section{RESEARCH METHOD}

This research used qualitative method. The variables analyzed in this research were the form and the function of local wisdom existed in the tourism area of Pusuk Buhit, Sianjur Mula-Mula Sub-district, Samosir Regency, North Sumatera Province, and their relations with the development of cultural tourism in Pusuk Buhit, Sianjur Mula-Mula Sub-district, Samosir Regency, and the tourists' responses to the existence of local wisdom in the tourism area of Pusuk Buhit, Sianjur Mula-Mula Subdistrict, Samosir Regency, North Sumatera Province. This research was conducted in the tourism area of Pusuk Buhit, Sianjur Mula-Mula Sub-district, Samosir Regency.

The research informants were the people who still had and practiced the rituals of local wisdom at Pusuk Buhit, Sianjur Mula-Mula Sub-district, Samosir Regency. They were the adat leaders, the people who understood the form and the function of local wisdom in 
the tourism area of Pusuk Buhit, Sianjur Mula-Mula Subdistrict, Samosir Regency, North Sumatera Province. They also understood the relation between local wisdom and the development of cultural tourism in the tourism area of Pusuk Buhit, Sianjur Mula-Mula Sub-district, Samosir Regency. The tourist was the one who makes tour for recreation.

The data were gathered by conducting interviews, in-depth interviews, and observation, using the guideline for interview with the local people, adat leaders, and the tourists who were in the tourism area of Pusuk Buhit, Sianjur Mula-Mula Sub-district, Samosir Regency, North Sumatera Province.

\section{RESULT AND DISCUSSION}

Sianjur Mula-Mula is a sub-district in Samosir Regency, North Sumatera Province, Indonesia. Its capital is situated at Ginolat Village. Sianjur Mula-mula is located in the main street which connects Doloksanggul with Sidikalang. The dominant clans in this area are Limbong and Sagala which are included in the Borbor clan.

Sianjur Mula-Mula can be categorized as the place of a historical site because this area contains a heritage such as buildings and other objects which have historical or archeological values. A site of archeological find is a place of the remaining activities of the olden days. These places are identified by the artifacts, the objects which are changed or modified by human beings, a certain kind of clay, the change in vegetation, irregular surfaces, and the like. It can be assumed that Sianjur Mula-mula subdistrict has a lot of historical heritage which has not been documented and managed well; besides that, this area has long been settled by the local people. For example, Sagala Village and Limbong Village as the old residential areas become the proof that there have been the activities of the people up to the present time which can be observed. Therefore, it can be concluded that the local people might possibly damage the historical heritage, especially the people who lack of knowledge about the importance of the sites of archeological find. It is no wonder if many of them are damaged and neglected.

\subsection{Form and Function of Local Wisdom in the Area of Pusuk Buhit, Sianjur Mula-Mula Sub- district, Samosir Regency}

There are some factors of local wisdom which can be identified at Pusuk Buhit, Sianjur Mula-Mula Subdistrict. Of the 38 identified types of local wisdom at Pusuk Buhit, Sianjur Mula-Mula Sub-district, nine of them are still preserved well, but the remaining 29 types of local wisdom are not. The story and the legend of all the 39 identified types of local wisdom in this area, according to the interviewed informants, are still believed by the people even though not all types of the local wisdom are remembered completely by the informants as what is described in Table 1 below:
Table 1. Identification of Local Wisdom in the Area of Pusuk Buhit, Sianjur Mula-Mula Sub-district, Samosir Regency

\begin{tabular}{|c|c|c|c|}
\hline No & Local Wisdom & $\begin{array}{c}\text { Conserve } \\
\text { d }\end{array}$ & $\begin{array}{c}\text { Believe } \\
\text { d }\end{array}$ \\
\hline 1. & Pusuk Buhit & $\sqrt{ }$ & $\sqrt{ }$ \\
\hline 2. & Batu Parrapotan & $x$ & $\sqrt{ }$ \\
\hline 3. & $\begin{array}{l}\text { Raga - raga na } \\
\text { Bolak, Raga-raga } \\
\text { Sombaon }\end{array}$ & $x$ & $\sqrt{ }$ \\
\hline 4. & Batu Kursi & $x$ & $\sqrt{ }$ \\
\hline 5. & Batu Sopo & $x$ & $\sqrt{ }$ \\
\hline 6. & $\begin{array}{l}\text { Batu } \\
\text { Martanggatangga }\end{array}$ & $x$ & $\sqrt{ }$ \\
\hline 7. & Batu Anduhur & $x$ & $\sqrt{ }$ \\
\hline 8. & Batu Palangka & $x$ & $\sqrt{ }$ \\
\hline 9. & Siharbangan & $x$ & $\sqrt{ }$ \\
\hline 10. & Batu Parbiusan & $x$ & $\sqrt{ }$ \\
\hline 11. & $\begin{array}{l}\text { Harangan Ruru- } \\
\text { onan }\end{array}$ & $x$ & $\sqrt{ }$ \\
\hline 12. & Harangan Etek-etek & $x$ & $\sqrt{ }$ \\
\hline 13. & Harangan Na Bolak & $x$ & $\sqrt{ }$ \\
\hline 14. & $\begin{array}{l}\text { Harangan } \\
\text { Sihumonong }\end{array}$ & $x$ & $\sqrt{ }$ \\
\hline 15. & Harangan Ganjang & $x$ & $\sqrt{ }$ \\
\hline 16. & $\begin{array}{l}\text { Tujuh Siharbangan } \\
\text { Pusuk Buhit }\end{array}$ & $x$ & $\sqrt{1}$ \\
\hline 17. & Batu Sondi & $x$ & $\sqrt{ }$ \\
\hline 18. & Aek Baringin & $x$ & $\sqrt{ }$ \\
\hline 19. & Aek Batu sawan & $\sqrt{ }$ & $\sqrt{ }$ \\
\hline 20. & Tala Tala & $x$ & $\sqrt{ }$ \\
\hline 21. & Batu Hobon & $\sqrt{ }$ & $\sqrt{ }$ \\
\hline 22. & Batu Gordang & $x$ & $\sqrt{ }$ \\
\hline 23. & Batu Simarlage-lage & $x$ & $\sqrt{ }$ \\
\hline 24. & Batu Gaja & $x$ & $\sqrt{ }$ \\
\hline 25. & $\begin{array}{l}\text { Batu } \\
\text { SiparimbuluBosi }\end{array}$ & $x$ & $\sqrt{ }$ \\
\hline 26. & Batu Raja Isumbaon & $x$ & $\sqrt{ }$ \\
\hline 27. & Batu Nanggarjati & $x$ & $\sqrt{ }$ \\
\hline 28. & Parik Sabungan & $\sqrt{ }$ & $\sqrt{ }$ \\
\hline 29. & Batu Rumabolon & $x$ & $\sqrt{ }$ \\
\hline 30. & $\begin{array}{l}\text { Batu } \\
\text { Parhusipansibatupar } \\
\text { eme }\end{array}$ & $x$ & $\sqrt{ }$ \\
\hline 31. & $\begin{array}{l}\text { Tulas dan Uluni } \\
\text { Sinabung }\end{array}$ & $x$ & $\sqrt{ }$ \\
\hline 32. & Batu Siungkappon & $x$ & $\sqrt{ }$ \\
\hline 33. & $\begin{array}{l}\text { Mual Sipultak Mata } \\
\text { Niari }\end{array}$ & $\sqrt{ }$ & $\sqrt{ }$ \\
\hline 34. & $\begin{array}{l}\text { Sijambur dan Jabu } \\
\text { Hela }\end{array}$ & $\sqrt{ }$ & $\sqrt{ }$ \\
\hline 35. & Mual Pongki Gading & $\sqrt{ }$ & $\sqrt{ }$ \\
\hline 36. & Mual Pansur Napitu & $x$ & $\sqrt{ }$ \\
\hline 37. & Mual Sipangolu & $\sqrt{ }$ & $\sqrt{ }$ \\
\hline 38. & Aek Sitopangi & $\sqrt{ }$ & $\sqrt{ }$ \\
\hline
\end{tabular}

Source: Result of Field Research 
Local wisdom in the area of Pusuk Buhit can be classified based on its form:

\section{The Form of Hill and Village}

Pusuk Buhit. Pusuk Buhit is called by the local people as a big and grand hill (doloknabadia, doloknabolon), the place for the Bataknese to pray (martonggo, martangiang). According to the Batak community, Pusuk Buhit is the origin of the Bataknese, belief (religion), cultural art, and adat (custom); it is also Gunung Suci (Sacred Mount) for the Bataknese.

Huta Parik Sabungan. It is the village of the early Siraja Batak. It is located at Sari Marrihit Village, Sianjur Mulamula Sub-district, which is identified by 3 (three) Batu Sabungan. The three of them are the symbol of the three gods (Batara Guru, Bala Sori, and Mangalabulan) and the symbol of three continents (Upper Continent, Middle Continent, and Lower Continent). Many legends about Guru Tetea Bulan come from this village.

Sijambur Mula and Jabu Hela. Sijambur Mula is a village cluster in the upper part of warm water tourism object (Aek Rangat) today, Siogung-Ogung Village, Pangururan Sub-district. Sijambur is the early village of Raja Isumbaon, the second child of Siraja Batak, after he had received the Book of Pustaha Teumbago Holing and Ompu Mula Jadi Na Bolon. Jabu Hela is a village in the form of a hill at Sijambur Nabolak, Tanjung Bunga, Pangururan. Since the house is given by Ompu Teteabulan to his son-in-law, it is called Jabu Hela. It is also known as the place of the descendants of Sorimangaraja worshipping idols (panjaut-jaut).

Pulau Tulas and Uluni Sinabung. Pulau Tulas is an island in Lake Toba, and Siboro Sianjur Mula-Mula Village is located on this island. In the old days, the owner of Pusuk Buhit used to be in conflict with the owner of Gunung Sinabung. In their fighting, the throat of Pusuk Buhit was cut off and fell into the lake and became Pulau Tulas. Tulas in the Bataknese local language means deceitful, insincere, and rebellious; therefore, Pulau Tulas becomes the warning for the next generation to be sincere and not to rebel.

Local wisdom can be in the form of village which can be the village of human beings and the village of the supernatural beings. Some researches on the existence of villages as local wisdom occurred to be in accordance with the nature and not damage it and maintaining its cultural identity (Wiradimadja, A, et. al., 2018; Hermawan, I, 2014), in order to hold tightly the tradition inherited from their ancestors (Zuhri, M. Tajudin and Ani Maliani, 2021). Besides that, there is also a village which used as the disaster mitigation. Asari Dan R and Hendriawan $N$ (2016) point out that the content of the values of local wisdom found in Naga Village concerning disaster mitigation based-environmental management such as 1) the values of discipline and honesty, 2) the value of religion, 3 ) the value of obedience, 4) the values of the sense of togetherness and cooperation, and 5) the values of simplicity, hospitality, and independency.

\section{The Form of Stone or Rock}

Batu Parrapotan. Batu Parrapotan is the stone of $\mathrm{Si}$ Raja Batak's ancestor used to make a decision or to discuss about the development of the huta (village). It is located in the area of Puncak (peak) of Huta Ginjang. It is the place of the fourth halt in the ritual of climbing up of Si Raja Batak. The ompu (grandfather) of Si Raja Batak stops here and prays for all inhabitants of Pusuk Buhit who often hold meetings in this place. This rock is known as the place of Dewa yang Tiga (the three gods) who held meetings discussing about the destiny of the souls of the deceased, especially the deceased that have passed to the heaven through the Peak of Pusuk Buhit.

Batu Kursi. Batu kursi (literally, chair stone) at Huta Ginjang of Pusuk Buhit which is believed to be the rest area of the Ompu Namartua Pusuk Buhit. However, some informants say that this place is believed to be the chair of Guru Teteabulan. Many people come to visit Batu Kursi because of their dreams.

Batu Sopo. Batu Sopo is considered as the place of begu (ghost), lelembut (trouble-making invisible spirit), and siluman (invisible forest elves). The stone is in the form of a sopo (house), but some people say that it is the place for storing offerings of Sirompur to be offered to Ompu Namartua Pusuk Buhit. Besides that, it is also said that Batu Sopo is the halting place of Ompu Mulajadi Na Bolon when he descends from Banua Ginjang to Sianjur Mula-Mula.

Batu Martanggatangga. Batu martangga-tangga is located at Parik Sabungan Village, Sianjur Mula-Mula Sub-district. Some people say that it is located at Sitaotao area, the place where Raja Odap-Odap walks from the area of Pusuk Buhit. According to folklore, Batu Sitangga-tangga is the steps of a ladder for Ompu Mula Jadi Na Bolon when he descends from Puncak Pusuk Buhit.

Batu Anduhur. Some people also call it the stone of truth owned by habonaran nihuta or the god of truth from a Bataknese village. It is located at Aek Baringin, Aek Sipitu Dai. It is the sitting/resting place of Ompu Namartua from where he can look at Sianjur Mula-Mula below.

Batu Palangka. It is a big rock located at Aek Baringin, Sipitu Dai. This rock is the place where Sorirompur pigs eat and lick their food. It is concave so that it is used to forge piso (knife) or podang (sword). Batu Palangka is also batu godang (big rock) at Pusuk Buhit.

Batu Siharbangan. Batu siharbangan is located at Aek Siputa Dai in the form of stone wall. It is the location of the gate for the guard of Mount Pusuk Buhit. It is also called batu pusuk buhit guarded by babiat (tiger). It is a stone gate which will firstly found when we visit Pusuk Buhit from Limbong.

Batu Parbiusan. Batu parbiusan is located at Aek Sipitu Dai in the form of one on top of the other stone. It is the place of the punguan (togetherness) of clans from some villages or the place where bius (community) of adat negotiates. Some people say that batu parbiusan is the place where offering of the bull head and other offerings are offered to Ompu Mula Jadi Na Bolon for the ritual to 
worship. This stone has been moved several times due to the migration. The last time it is located in the people's coffee plantation so that it is neglected.

Batu Sondi. Batu sondi or liang sakti is a stone cave at Parik Sabungan, Sarimarihit Village, Siajur Mula-Mula Sub-district. Sondi means bed; it is located on sawan stone, the hiding place of Raja Biak-Biak or Raja Uti. Some people say that sondi is storage. Batu sondi or liang sakti is the place where Ompu Raja Uti is isolated by his parents in order to avoid being insulted by his little brothers because when he is born he has round body, does not have any bones and legs so that he is considered queer by his brothers.

Batu Hobon. Batu hobon is located in Sianjur MulaMula. It is the place where Saribu Raja keeps his heirlooms. Hobon means trunk made of stone. The heirlooms kept in the batu hobon are bukulak-lak, a set of musical instruments (gongs), knives, magical barriers, medicines, and batu gosok emas (gold rubbing stones)

Batu Gordang. Batu gordang is located at Aek Sipitu Dai Village, Sianjur Mula-Mula Sub-district. According to the folklore, this rock cannot be moved from its place. When it is moved to another place, batu gordang will come back to its former location, in the pintu sona, Batu gordang is used as the place of sibiaksa. Biaksa is a human being that is cut up, burned, and his oil is taken. It is called batu gordang because it can become gendang (kettledrum) for a musician like Ompu Namartua Pusuk Buhit.

Batu Simarlage - lage. Batu simarlage-lage is located at Si Pitu Dai Village, Sianjur Mula-Mula Sub-district. It is a big rock which has flat surface like a floor made of stone (lage) as a place for sitting (parhundul-hundulan). It is said that this rock is the sitting place of Ompu Namartua Pusuk Buhit while he is listening to kettledrum ritual in Sianjur Mula-Mula.

Batu Gaja. Batu gaja looks like the form of an elephant located on the peak of Huta Ginjang, Sianjur Mula-Mula Sub-disrict. It is a stone-tablet for remembering the aide, an elephant, of Ompu Guru Teteabulan and Ompu Si Boru Sakti. This elephant has supernatural power which can make the earth shake when it swings and tread on the earth. Therefore, elephant is considered sacred by the Bataknese.

Batu Siparimbulu Bosi. Batu siparimbulu Bosi is located at Tala, Huta Ginjang Village, Sianjur MulaMula Sub-district. Siparimbulu Bosi is Dewata Asi-Asi who guards Gerbang Pusuk Buhit (Pusuk Buhit Gate). Batu siparimbulu Bosi has the form of two animals: elephant and horse as the ridden animals of the guard of Pusuk Buhit Gate.

Batu Raja Isumbaon. Batu Raja Isumbaon is a round rock on the Peak of Huta Ginjang, siogung-ogung tanjung bunga. It has been the mark of Raja Isumbaon. It is the place where people get water which is believed to be able to heal various illnesses. This rock is considered as the realization of Ompu Raja Isumbaon. It also becomes the departure stone of Ompu Rajja Uti from Pusuk Buhit and becomes the arrival place at Pusuk Buhit after returning from a journey.
Batu Nanggarjati. Batu nanggarjati is located on another rock at Siarsam Sari Marihit, Sianjur Mula-Mula. It is a big, flat rock on the top of a hill, on Batu Hobon. In the Bataknese myth, it is a very important place which is called a portal, the road to the upper world (banuaginjang). Batu nanggarjati is the place where Tuan Saribu Raja forges various tools and equipment made of iron/metal such as gongs and sharp weapons.

Batu Ruma Bolon. Batu Ruma Bolon is located at Sarimarihit Village, Sianjur Mula-Mula Sub-district. It is close to Batu Martangga-tangga, Batu Sopo in the west weist of Pusuk Buhit, above Aek Baringin and Parik Sabungan. Batu Ruma Bolon is one of the big rocks in the form of Batak big house (Ruma Bolon), complete with its walls, pillars, and stone roofs. It is believed to be the stopping place of Ompu Mulajadi Na Bolon when he descends from Peak of Pusuk Buhit to Sianjur MulaMula and returns to Pusuk Buhit.

Batu Parhusipan Sibatu Pareme. Batu Parhusipan is some rocks which are gathered in one place at Sarimarihit Limbong Village, Sianjur Mula-Mula Sub-district. This rock is the place where Tuan Saribu Raja and Siboru Pareme establish their love (marhusip). Saribu Raja is close to Siboru Pareme, his younger sister (ito). Since it is a deviating act and immoral, an incest between brother and sister, it is really a deviating behavior. The story of incest is told to people, and the conclusion is that Siraja Lontung and his descendants are illegitimate, Parik Sabungan.

Batu Siungkap-ungkapon. Batu Siungkap-ungkapon is located close to Tano Ponggol. It is a rock installed by Raja Isumbaon to cover a very deep hole which is called, Lubang Naga Padoha (Naga Padoha Hole). This hole is sulfur flashes mixed with hot water from underground because Mount Pusuk Buhit is an active volcano. This hole is also functioned as a road and a portal toward the under world.

There are about 18 stone sites as a local wisdom location which can be identified. Basri, et. al. (2020) in their research point out that stone sites can be used as the source of learning history, such as Batu Berak Site which has historical values. It can be used as the optimization in learning Indonesian history, especially in the prealphabetical symbol era by recognizing more the stone age culture. A research conducted by Rusyanti, R (2021) shows that there is the similarity in the stone characteristics in the traditional houses at Liwa, Kenali, and Canggu with stone artifacts found in the sites of archeological find at DAS Way Semangka. The rocks are assumed as the remaining umpok or foundation stone of Lampung traditional building structure made with traditional construction technique, kalindang, earthquake-resistant. Umpaak stone made from tuff and pumice is unique because it is light, easily molded, and has superiority as light concrete materials. The use of tuff and pumice as umpak construction is the proof that local wisdom is still preserved in West Lampung.

\section{The Form of Altar}

Raga Raganabolak or Ragaraga Sombaon. Wide altar (Raga raganabolak) is an altar to do worship (pemelean) 
or to offer offerings and to pray. Raga-raga Nabolak (wide altar) or Raga-raga Sombaon (Altar for praying) is the highest peak since there are three peaks of Mount Pusuk Buhit:

1. The peak on Sigulanti is the peak of the oldest child of Si Raja Batak, Guru Teteabulan;

2. The peak on Sijambur Mula is the peak of the second child of Si Raja Batak, Raja Isumbaon; and

3. The highest peak is the peak of Dewata Na Tolu and Ompu Mula Jadi Na Bolon, the most sacred and holiest peak for the Bataknese.

\section{The Form of Forest}

Harangan Ruru Onan. Harangan is a forest in Bataknese local language. Harangan Ruru Onan is located at Si Boho, Sianjur Mula-Mula Sub-district. This forest is the place of Si Raja Na Bimbinan, one of the persons who is selected to inherit the supernatural power of Ompu Raja Uti. Harangan Ruru Onan is a small forest where some types of tree grow in cluster in it.

Harangan Eteketek. Eteketek means small in the Bataknese local language so that harangan eteketek is translated to small forest where various types of tree grow. This forest is the rest place of Ompu Parimbulu Bosi. He will look at the land of Sumatera from this place. This forest is dwelled by begu (ghost), lelembut (troublemaking invisible spirit), and siluman (invisible forest elves). The siluman can behave negatively and positively, depended on who comes to this place.

Harangan Nabolak. Harangan $\mathrm{Na}$ Bolak is located at Huta Ginjang, Sianjur Mula-Mula Sub-district. The forest is the sacred limitation among villages (huta) in Sianjur Mula-Mula Sub-district with the sacred area in the area of the Peak of Pusuk Buhit which becomes the place of Parbanua Na Ginjang. Nabolak means wide so that Harangan Na Bolak is dwelled by siluman and lelembut.

Harangan Sihumonong. Harangan (forest) Sihumonong is located on the peak of Mount Pusuk Buhit. It is a forest before the peak of Puncak Pusuk Buhit from Hutaginjang. Even though this forest is not very wide, many people get lost in it because a modest person who can be safe getting out from this forest without getting any problem. This forest is the cave (liang) of Raja Uti, liang of Raja Batak. This cave is the place where they can get rest or a shelter.

Harangan Na Ganjang. Harangan (forest) Na Ganjang is located at Sipiso-piso. It is a dense forest, full of various types of tree, starting from Sigulanti until toward Aek Sitapangi. It used to be very terrifying because it is dwelled by wild animals such as tigers, but since it has been burned down, there are only some trees left in the Harangan Na Ganjang as the remnants, due to the aid of nature. In accordance with Harangan Sihumonong, this forest is full of the invisible spirits which are worshipped by the Bataknese. This forest is neglected and abandoned. In the study of local wisdom, forest is usually related to the effort to preserve it, as it is made by Salosa, et. al., (2014) who point out that a forest plays very important role in the people's lives, especially in applying accurate strategies to conserve the forest and to accommodate the people's interest so that it is expected that it is based on people's wisdom in using the forest. The same is true to the research done by Sarkawi (2010) which states that the Kajang people are successful in maintaining their forest due to "local wisdom" which is called, pasang. Pasang is the value which contains message, advice, guideline, or the required way of life in order to achieve happiness in the world and in the afterlife.

People believe that the balance of the world created by "Turie 'A 'ra 'na" should be maintained. The whole system of nature conservation in Tanah Kajang is related to the local people's point of view on nature. They believe that in nature there is a mysterious power; if it is not handled well, it will cause calamity. Openg (2015), in his research, shows that Oel Taekas Mamar is one of the types of the ecological wisdom of the adat community of Atoin Meto that has important resources of betel nuts which have economic value, water infiltration area, spiritual center, and social integration center. The people conserve forest and natural water springs through the adat and myth of Nais Tala. The mythology which exists in the adat society states that stones and wood in the sacred forest are the incarnation of the ancestors. The adat community of Atoin Meto in Femnasi realizes that human beings need to have harmonious relationship with forest area so that there will be a reciprocal harmony.

\section{The Form of Water Spring}

Tujuh Siharbangan Pusuk Buhit. It is located beside Batu siharbangan as the name and the mark of an area. The seven water springs (siharbangan) are Siharbangan at Sipitu Dai (AekSipitu Dai water spring), Siharbangan at Boho Village (Aek Sibaringin water spring), Siharbangan at Tanjung Bunga Village (aekparsuangan water spring), Siharbangan at Si Ogung-ogung (Batu Gaja) (Aek Sipultak Mataniari water spring), Siharbangan at Tulas (Aek Bona-bona water spring), Siharbangan at Lumban Parit Village (Aek Manggaja water spring), and Siharbangan at Sigulanti (Bintatar water spring).

Aek Baringin. Aek Baringin is located at Aek Sipitu Dai, Sianjur Mula-Mula Sub-district. It is a water spring emerging from the roots of banyan tree. The water emerges from the pile of big stones assembled in that place and forms round ditches. Many trees grow on the stones so that their roots bind the stones and the roots tightly. Its location is cultivated by the local people who make it a coffee smallholder.

Aek Batu Sawan. Batu Sawan is located in the western part of Mount Pusuk Buhit at Parik Sabungan, Sarimarihit Village, Sianjur Mula-Mula Sub-district. It is in the form of a cup which functions as the bathing place of Raja Biak-Biak or Raja Uti in the hope that he will have a prime body as other normal human beings. Aek Batu Sawan is believed to have a supernatural power to handle kesurupan (animated and dominated by an evil spirit), the place to ask for offspring and good income, getting passed in examinations, and recovery from illness. 
Tala tala. Tala-tala, in the form of small basin, is located in the area of Huta Ginjang, Sianjur Mula-Mula Sub-district. It is situated in front of Batu Parrapotan. Its water is believed to be able to cure (tawar) from Siraja Batak; it can be medicine (tawar) and make someone have supernatural power. However, it is now dry up; there are some holes in it because people want to get its water and because they also want to get dirt from it.

Mual Sipultak Mata Niari. Mual Sipultak Mata Niari is a water spring, located at Sijambur Nabolak, Tanjung Bunga, Pangururan. It is one of the water springs located in the corner (suhi) of Sianjur Mula-Mula. Therefore, this water spring used to be used as the border line between two villages. It is located in the eastern part of Pusuk Buhit and owned by Raja Isumbaon. Even though the water spring has been dried up and forgotten, it can be identified as one of the Batak historical benchmarks since it is mentioned in the Bataknese myth. The water spring is functioned as the device to separate the sun rises (perhabissaran) and the sun sets (perhasuddutan), between the descendants of Guru Teteabulan and the descendants of Isumbaon.

Mual Pongki Gading. The water spring Si Pongki Gading excretes water from a trunk of wood in Sagala.

Mual Pansur Napitu. Mual Pansur Na Pitu is also called Pansur jabi-Jabi Si Pitu Dai. Its water spring is at Limbong. It has 7 (seven) water springs coming out from the roots of jabi-jabi tree. The water spring of Pansur Napitu is quite unique because the water comes out from seven fountains which are believed to have different tastes.

Mual Sipangolu. Mual Sipangolu is also called Aek Sipaulak Hosa and similar to Aek Bintatar in Sagala today. The water spring is located in the valley on the foot of a hill. It used to be the source of water of Siboru Pareme (Puteri Guru Teteabulan) after they moved to a new village in Sagala. This water spring is regarded as blessing and refreshing water. It is believed to be the source of life. There is a Bintatar tree growing on it so that it is also called Aek Bintatar.

Aek Sitapangi. Aek Sitapangi is a reservoir in the area of the Peak at Huta Ginjang. It is known as Lintong Simajo-ajo, a reservoir full of oma-oma. It is the place of the fifth rest area since it is the bathing place of the gods' children. According to the myth, this reservoir was created by Ompu Mulajadi $\mathrm{Na}$ Bolon as the bathing place and self-purging (paranggiran).

In accordance with the explanation above, the research conducted by Sumarmi (2015) indicates that the local wisdom of Osing community in managing their water resources includes knowledge, values, morality, ethics, and norms which are applied in the form of suggestions, rules and sanctions, and the words of wisdom as the guidelines for them to behave and to act in maintaining and conserving water spring of Mbah Buyut Citi. In order to keep the discharge constant, they protect trees and plants in the spring time (belik), either belik lanang or wadon belik. In maintaining this local culture, the old generation bequeathed values, morality, ethics, and norms, including the Islamic norms (most of them are
Moslems) as the guideline about how to behave and to act in accomplishing their tradition and instinct in order to pay homage to their families, neighbors, relatives, and descendants. Messakh, et. al (2015) point out that even though the water source potentially exists, it is difficult to get drinking water. In order to solve this problem, the paradigm of managing water resources for the need of multi-sectors should be adjusted to the specification of a certain semi-arid region by prioritizing the need for drinking water. The potency of rainfall should be optimized as standard water source through the construction of reservoir, other facilities of rain water receptacle, and conservation. Retrenchment of using water should be in accordance with the need and local wisdom, and regulation on priority of service area for the system of water piping are the other strategies which can be done. The use of ground water as the main water source should be controlled by considering environmental supporting power.

Tourism development at Pusut Buhit is not only concerned with enjoying the beautiful panorama of Lake Toba but also concerned with religious and historical tours with the whole local wisdom surrounding Pusuk Buhit. The result of interviews with the tourists who visited Pusuk Buhit showed that most of the tourists suggested that they need guides who were able to convey religious and historical values of local wisdom at Pusuk Buhit. Every local wisdom surrounding Pusuk Buhit should have guides who were able to tell and know the origin of the places they were visiting. However, the tour guides in Pusuk Buhit only accompany the tourists to the tourism objects without giving any explanation. The tourists also suggest that manuals be provided for them by the government for being used as education and also cultural preservation and stories from generation to generation. Moreover, understanding about local wisdom of tourism objects in Sianjur Mula-Mula is different in each speaker in the location of social wisdom. Local wisdom literacy in Sianjur Mula-Mula Pusuk Buhit tell much about legends from religious point of view.

From the interview with the tourists, it was found that tourism development should be followed by the creativity of the local people surrounding a tourism object and by the transparency in retribution income. The result of observation and interview showed that there was no creativity of the local people and the transparency in retribution. Improvement in the location of local wisdom can be done without changing the form or adding something which can disturb the local wisdom at a tourism object. The local people should be understood and given socialization to maintain security and order in the tourism object. Continuous active facility or institution which is functioned to trigger and encourage the guarding and securing local wisdom should be needed.

Most of the local wisdom surrounding Sianjur MulaMula visited by the tourists who make religious tours and who come from the outside Samosir is about pilgrimage destination. They visit the tourism objects in order to look at the heritage from their ancestors. They pray for their 
health and prosperity, for their recovery from illnesses, and for being avoided from danger. Very few tourists come to see or are interested in mystical stories and sacred local wisdom. Excluded from the pilgrims, very few tourists visit the area of Pusuk Buhit because most of them do not know the existence of local wisdom in the area of Pusuk Buhit. Even though they know it, they are reluctant to visit it. The problem is that it is difficult for them to get the access to the tourism object since it is far from their hotels, they need extra energy to reach Pusuk Buhit, there is no special transportation to carry them to the local wisdom location, very little information available about the local wisdom, lack of service in the area of local wisdom, there is no facility for them to take a rest, lack of toilets and bath-rooms, and lack of restaurants or food stands. Besides that, the sanitation and hygienic condition of some places of water sources in the local wisdom areas are very bad such as a lot of rubbish everywhere. It means that the existence of local wisdom location in the area of Pusuk Buhit does not encourage tourists to visit since most of them visit the local wisdom location in the area of Pusuk Buhit are pilgrims (religious tours).

Based on the result of observation, it was found that it is rarely found a person who understands and knows much about the legends, the stories of local wisdom in Samosir, especially in Pusuk Buhit, Sianjur Mula-Mula Subdistrict. This is because the lack of literature or reading materials about the local wisdom. The stories about it are also not clear enough since there are many versions about it today. Besides that, the stories or legends are not transmitted to the young generation and there is no subject concerning it in schools. The parents know these stories and the legends not from their parents but from inspiration through dreams or omen created by their ancestors. Some people even say that they get the omen from their ancestors so that the stories become uncertain and unreliable.

Some pilgrims who come from the outside Samosir also have their own versions; therefore, some of them violate the adat (custom) when they pray (martonggo) in the local wisdom location. Some pilgrim or tourists build their own monuments and perform queer rituals excluded from the stories believed by the local people.

Tourists from the outside Batak Toba also visit Pusuk Buhit and perform their own rituals in the local wisdom location at Pusuk Buhit, Sianjur Mula-Mula. Some Chinese also come to the local wisdom location by bringing incense, fruit, etc., while they perform their rituals and pray in some places of the local wisdom. The local people frequently find some fruit and incense which is still burning. There are also the Javanese who come to the local wisdom in Sianjur Mula-Mula, bringing flowers, betel leaves, incense, and roosters, and they bathe, too.

The followers of the Belief in Parmalim often perform rituals in the local wisdom location. This is not contrary to the local people who are the followers of Christianity. The same is true to the followers of the Belief in Parbaringin who consider that the local wisdom is the objects from their debata (god) which should be guarded and maintained.

Parbaringin is not the same as the sects in Christianity which we know today. Its followers do not have unity; they do their rituals individually or with their own families, and they also do not have any priests. Their activities are based on what they get from their ancestors through dreams (inspiration).

\section{CONCLUSION}

1. Of the 38 types of local wisdom identified in the Area of Pusuk Buhit, Sianjur Mula-Mula Subdistrict, only 9 (nine) of them are maintained well while the remaining 29 of them are not. The stories and the legends of the identified local wisdom are still believed.

2. The types of Local wisdom identified at Pusuk Buhit, Sianjur Mula-Mula, can be classified into 5 (five) forms: the form of Hill and Village, the form of Stone or Rock, the form of Altar, the form of Forest, and the form of Water Spring

3. Most of the tourists who visit the local wisdom location in the area of Pusuk Buhit, Sianjur Mula-Mula Sub-district, do religious tour; they come to perform their pilgrimage to the local wisdom location.

4. Stories about the local wisdom are not uniform, and they are usually interpreted by the speakers differently, based on their own religion.

5. Why tourists generally are reluctant to visit the local wisdom location is because of lack of transportation to the location, the location is far from the hotels where the tourists stay, there is no inn or motel in the local wisdom location, tourists need extra energy to reach the area of Pusuk Buhit, lack of information about the existence of the local wisdom, lack of service in the local wisdom location, lack of facility for the tourists to relax, lack of toilets/bath rooms, lack of restaurants or food stands, and sanitation and hygienic condition in the local wisdom location are very bad,

6. The existence of local wisdom in the area of Puuk Buhit does not encourage tourists to visit it.

\section{SUGGESTIONS}

1. Socialization about the existence of local wisdom location in the area of Pusuk Buhit, Sianjur Mula-Mula Sub-district, needs to be socialized, and the transportation access to the local wisdom location should be improved;

2. Training for the speakers of local wisdom stories is needed so that they will be uniformed and not be interpreted differently;

3. Prime service is highly needed by expressing hospitality of the local people and tour guides toward tourists by providing food stands with halal food, along with its price lists, providing 
clean and hygienic toilets, and the water springs are free from rubbish.

\section{ACKNOWLEDGMENTS}

We acknowledge the support received from the Ministry of Education and Culture of the Republic of Indonesia. In addition, we also want to thank you for the attention and support from the Universitas Sumatera Utara.

\section{REFERENCES}

[1] Ahimsa-Putra, Heddy Shri. 2009. Bahasa, Sastra dan Kearifan Lokal di Indonesia. Mabasan. Vol. 3 No. 1 Januari-Juni 2009: p.30-57.

[2] Andriani R. et al., 2019. Value Tari Sigale-gale Dalam Meningkatkan Wisata Budaya di Desa Tomok Kabupaten Samosir. Journal of Indonesian Tourism, Hospitality and Recreation.

[3] Aswita D. et al., 2018. Local wisdom of Sabang Island society (Aceh, Indonesia) in building ecological intelligence to support sustainable Tourism. Geojournal of Tourism and Geosites.

[4] Buaton K dan Purwadio H. 2015. Kriteria Pengembangan Kawasan Wisata Danau Toba Parapat, Sumatera Utara. Jurnal Teknik ITS. Vol.4. No.1, C1-C5.

[5] Field, John. 2010. Modal Sosial. Terjemahan Nurhadi. Bantul, Kreasi Wacana.

[6] Harahap, R.H. and Humaizi. Local wisdom in preservation of Lake Toba ecosystems (study on Toba Lake community in the Village of Silalahi I, Sub District of Silahisabungan, Dairi Regency, North Sumatera Province). IOP Conference Series: Earth and Environmental Science. Vol.126, Friendly City 4 'From Research to Implementation For Better Sustainability' 11-12 October 2017, Medan, Indonesia.

[7] Irsal I. et al. 2020. Model Arrangement of the Meat Village as an Alternative Tourism Destination of Toba Lake. IOP Conference Series: Earth and Environmental Science.

[8] Jaya I. 2019. Environmental Management of Lake Toba Tourism Area Indonesia. Budapest International Research and Critics Institute (BIRCIJournal): Humanities and Social Sciences.

[9] Keliat, R.B. dan Dwira Nirfalini Aulia, 2020. Kajian Peruntukan Tanah Desa Sitamiang Menuju Desa Wisata Berbasis Kearifan Lokal. Talenta Conference Series: Energy and Engineering (EE).

[10] Lumbanraja P.et al. 2019. Sustaining lake toba's tourism: Role of creative industry, green tourism marketing and tourism experience. Asian Journal of Business and Accounting.

[11] Mahulae P. J., M. 2019. Deskripsi Permasalahan Upaya Pengembangan Pariwisata Berkelanjutan di Danau Toba Sumatera Utara (Problem Description of Sustainable Tourism Development Effort on Toba Lake North Sumatera. Inovasi.

[12] Maturbongs, E.E. and Ransta L. Lekatompessy. 2020. Kolaborasi Pentahelix dalam Pengembangan Pariwisata Berbasis Kearifan Lokal di Kabupaten Merauke. Transparansi : Jurnal Ilmiah Ilmu Administrasi, Vol.3, No.1, Juni 2020, p.55-63. http://ojs.stiami.ac.id jurnal.transparansi@stiami.ac.id transparansijournal@gmail.com

[13] Mungmachon M. R., 2012. Knowledge and local wisdom: community treasure. International Journal of Humanities and Social Science. Vol. 2, No.13, p.174-181.

[14] Nawatnatee, T dan Noppamash S., 2014. Local Wisdom to Creative Cultural Tourism Activity. Journal of Tourism and Hospitality Management. Vol. 2, No. 2, 77-84. Khon Kaen University, Khon Kaen, Thailand.

[15] Panggabean F. Y et al. 2020. Eksplorasi Produk Unggulan Desa Tomok. Jurnal Penelitian dan Pengabdian Kepada Masyarakat UNSIQ.

[16] Pardede, Fransiska Roslila Eva Purnama dan Suryawan, Ida Bagus Suryawana, 2016. Strategi Pengelolaan Kabupaten Samosir Sebagai Daya Tarik Wisata Alam Di Provinsi Sumatera Utara. Jurnal Destinasi Pariwisata, Vo.4 No.1, hal 14-19.

[17] Pasaribu G dan Sahwalita. 2006. Pengolahan Eceng Gondok Sebagai Bahan Baku Kertas Seni. Ekspose Hasil-Hasil Penelitian. Konservasi dan Rehabilitasi Sumberdaya Hutan.

[18] Siregar, S dan T. Rajagukguk. 2018. Analisa Kearifan Lokal Terhadap Pengembangan Ekonomi Lokal Usaha Mikro Kecil Dan Menengah Di Wisata Danau Toba Kecamatan Girsang Sipangan Bolon Kabupaten Simalungun. Jurnal ilmiah methonomi.

[19] Siregar R. et al. 2018. Pengembangan Kawasan Pariwisata Danau Toba, Kabupaten Samosir. Tataloka.

[20] Siregar A. Z. 2008. Pengelolaan Ekosistem Kawasan Danau Toba Tanggungjawab Siapa?. Repository USU-Medan.

[21] Situmorang, V. et al. 2019. Applying Opinion Mining Technique on Tourism Study Case: Lake Toba. Journal of Physics: Conference Series.

[22] Sianturi T. 2004. Degradasi Danau Toba. Jurnal Penelitian Bidang Ilmu Pertanian.

[23] Sinaga A. P. 2018. Aspek Inovasi dan Teknologi Dalam Pengembangan Kawasan Danau Toba di Kabupaten Samosir. Inovasi.

[24] Sihombing D et al. 2019. Community Tourism Awareness Influence Against Tourism Development and Regional Development in North Tapanuli Regency, Indonesia. International Journal of Civil Engineering and Technology.

[25] Syahra, Rusydi, 2003. Modal Sosial: Konsep dan Aplikasi. Jurnal Masyarakat dan Budaya, Vol. 5, No.1, p. 1-22

[26] Revida E. et al., 2018. The influence of social capital towards the quality of community tourism 
services in Lake Toba Parapat North Sumatera. IOP Conference Series: Earth and Environmental Science.

[27] Tri Yudha W, M dan Nirfalini Aulia D. 2019. Penataan Ruang Tepi Air Untuk Pengembangan Kawasan Ekowisata Di Tano Ponggol, Talenta Conference Series: Energy and Engineering (EE).

[28] Tamba T. 2020. Relational Theology: A Critical Theological Review of Ecological Damage in the Lake Toba Area According to the Fretheim's Perspective, Jurnal Teologi Cultivation.

[29] Usman, Sunyoto. 2005. Esai-Esai Sosiologi Perubahan Sosial, Jogjakarta: Pustaka Pelajar

[30] Utami W et al. 2019. Studying Resilience on Urban Cultural Landscape Heritage, IOP Conference Series: Earth and Environmental Science (2019).

[31] Widhijanto A. A. dan Tisnaningtyas E. Y. 2018. Identifikasi Kawasan Permukiman Pendukung : Analisis Proximity Pengembangan Destinasi Wisata Danau Toba. Neo Teknika.

[32] Wiradimadja, A. Et all. 2018. Kearifan Lokal Masyarakat Kampung Naga Sebagai Konservasi Local Wisdom of Kampung Naga Community as Natural. Jurnal Pendidikan Humanis. Vol.3. No1. 1 Juli 2018.

[33] Zuhri, M, Tajudin dan Ani Maliani. 2020. Internalisasi Nilai Pendidikan Karakter Pada Masyarakat Adat Kampun Pulo dalam Pembelajaran Nilai-Nilai Kementrian Energi dan Sumberdaya Mineral. Jurnal Aparatur. Vol.4.No.1. Februari 2020.

[34] Hermawan, I. 2014. Bangunan Tradisional Kampung Naga : Bentuk Kearifan. Jurnal Sosio Didaktika.

[35] Asari Dan R dan Hendriawan N. 2016. Kajian Nilai Kearifan Lokal Masyarakat Adat Kampung Naga Dalam Pengelolaan Lingkungan Berbasis Mitigasi Bencana. Prosiding Seminar Nasional Geografi UMS Upaya Pengurangan Risiko Bencana Terkait Perubahan Iklim (2016).

[36] Basri, M. et all. 2020. Nilai-nilai Sejarah Berbasis Local Wisdom Situs Batu Berak Sebagai Sumber Pembelajaran Sejarah. Gulawentah: Jurnal Studi Sosial. Vol. 5, No. 2, Desember 2020.Hal :125-131.

[37] Rusyanti, R. 2021. Umpak Batu : Jejak Konstruksi Bangunan Masa Lampau Di Lampung Barat (Colomn Base : The Traces Construction in West Lampung). Kindai Etam : Jurnal Penelitian Arkeologi (2021), 10.24832/ke.v7i1.91

[38] Salosa, S.T. et all. 2014. Hutan Dalam Kehidupan Masyarakat Hatam Dalam Di Lingkungan Cagar Alam Pegunungan Arfak. Jurnal Manusia dan Lingkungan. Vol.21.No.3. November.: 349-355.

[39] Sarkawi, B.H. 2010. Pasang Ri Kajang: Pasang Sebagai Modal Sosial dalam Pengelolaan Hutan oleh Masyarakat Adat Ammatowa Kabupaten Bulukumba Sulawesi Selatan. Masyarakat, Kebudayaan dan Politik (2010).
[40] Sumarmi, S. 2015. Local Wisdom of Osing People in Conserving Water Resources. Jurnal Komunitas : International Journal of Indonesian Society and Culture.

[41] Messakh, J. et all. 2015. Kajian Pemenuhan Kebutuhan Air Minum Untuk Masyarakat Di Kawassan Semi-Arid Indonseia. Jurnal Manusia dan Lingkungan.

[42] Openg V, Kapitan. 2015. Mamar Sebagai Kearifan Ekologi Masyarakat Adat Atoin Dalam Kaitan Pelestarian Sumberdaya Air di Desa Femnasi, Timor Tengah Utara. Humanis. 